\title{
Chronic Chlamydophila pneumoniae infection in lung cancer, a risk factor: a case-control study
}

\author{
Bekir Kocazeybek
}

\begin{abstract}
Correspondence
Bekir Kocazeybek

bekirkcz@superonline.com
\end{abstract}

Received 3 December 2001

Accepted 21 January 2003

\author{
Cerrahpașa Faculty of Medicine, Istanbul University, Department of Microbiology and Clinical \\ Microbiology, Istanbul, Turkey
}

\begin{abstract}
The relationship between chronic Chlamydophila (formerly Chlamydia) pneumoniae infection and lung carcinoma was investigated. A total of 123 patients who were smokers and diagnosed with lung carcinoma based on clinical and laboratory (radiological, cytological) findings were examined. Of these patients, 70 had small-cell, 28 squamous-cell and seven large-cell carcinomas, while 18 had adenocarcinoma. A total of 123 healthy persons matching patients in age, sex, duration of smoking and locality were chosen as controls. Blood samples $(5 \mathrm{ml})$ were withdrawn at the time of diagnosis and 1 month later. The values between $\lg G \geqslant 512$ and $\lg A \geqslant 40$ were set as the criteria for chronic Chlamydophila pneumoniae infections. In male patients with lung carcinoma, Chlamydophila pneumoniae $\operatorname{lgG}$ antibody titres of $\geqslant 512$ and $\lg A$ antibody titres of $\geqslant 40$ were found at a higher rate than in the control group. This ratio was not significant for the female patients. In chronic Chlamydophila pneumoniae infections, Chlamydophila pneumoniae antibody titres with values $\lg G \geqslant 512$ and $\lg A \geqslant 40$ were found in a total of $62(50.4 \%)$ cases. Chronic Chlamydophila pneumoniae infections were seen statistically more often in male patients with carcinoma who were aged 55 years or younger. This study supports the idea that chronic Chlamydophila pneumoniae infection increases the risk of lung carcinoma.
\end{abstract}

\section{INTRODUCTION}

Chlamydophila (formerly Chlamydia) pneumoniae, and previously also known as strain TWAR, is a Gram-negative bacillus and an obligatory intracellular parasite (Grayston, 1989; Everett et al., 1999). It causes infection in more than $50 \%$ of adults. It leads to a higher incidence of pneumonia in the elderly, while children younger than 5 years old have less clinical infection (Saikku, 1992). Chlamydophila pneumoniae infections vary in different countries and populations, being endemic in the USA and epidemic in Scandinavian countries. The route of transmission is usually by aerosol and respiratory secretions (Grayston, 1989; Thom \& Grayston, 1991). Since it is difficult to isolate the organism in culture, serological analysis is preferred in diagnosis. However, it could not be established as a routine method due to very few elementary substances in samples (Grayston et al., 1990). PCR, known to be $25 \%$ more sensitive than culture, is often used for diagnosis, but serum antibody determination, especially microimmunofluorescence (MIF), is the most frequently used method for the diagnosis of chlamydia infections (Gaydos et al., 1993; Grayston, 1994). Chlamydophila pneumoniae causes various infections, such as pneumonia, sinusitis, bronchitis, rhinitis, chronic obstructive pulmonary disease (COPD) or asymptomatic infection.

Abbreviations: COPD, chronic obstructive pulmonary disease; MIF, microimmunofluorescence.
The specific antibody titres of Chlamydophila pneumoniae have been found to be high in myocardial infarction, stable angina pectoris and atherosclerosis cases. In addition, detection of Chlamydophila pneumoniae in atherosclerotic plaques on coronary and carotid arteries, led to discussion about the cause-effect relationship between Chlamydophila pneumoniae and atherosclerosis and coronary heart disease (Saikku et al., 1988; Grayston et al., 1993; Arat et al., 1999). In the last 3 years, seroepidemiological studies have indicated a possible relation between Chlamydophila pneumoniae infection and lung carcinoma and malignant lymphoma (Koyi et al., 1999; Laurila et al., 1997a). In this study, we aimed to evaluate the relationship between chronic Chlamydophila pneumoniae infection and lung carcinoma by determining antibodies against Chlamydophila pneumoniae in patients with lung carcinoma who are smokers.

\section{METHODS}

A total of 123 cases diagnosed as primary lung carcinoma with clinical symptoms and laboratory findings (radiological, cytological) consisting of $70(56.91 \%)$ small-cell carcinoma, $28(22.76 \%)$ squamous-cell carcinoma, 18 (14.63\%) adenocarcinoma and seven (5.69\%) large-cell carcinoma cases, were included in this study. The subjects were admitted to the Oncology and Lung Diseases Departments in the Florence Nightingale Group between 1 June 1998 and 1 July 2000. One hundred and one $(82 \cdot 11 \%)$ of the cases were male and $22(17.88 \%)$ were female, with ages between 22 and 87 and a mean of 55 years (53 
males were $<55$, 48 were $\geqslant 55$ years old; 10 females were $<55$ and 12 were $\geqslant 55$ years old). The duration of smoking before the diagnosis of primary lung carcinoma was between 3 and 58 years with a mean of 32 years. A control group of 123 people was chosen from among healthy hospital staff, relatives of the patients, blood donors or persons with similar age, sex and smoking habits. In the selection of the control group, the following criteria were taken into consideration: age, sex, living environment, smoking history, including the following: age of starting smoking, whether or not he or she is still a smoker, number of cigarettes per day, duration of smoking, and if smoking stopped, total time of smoking.

Of the control group, $101(82 \cdot 11 \%)$ were males and $22(17 \cdot 88 \%)$ were females. Their ages were $22-87$ years with a mean of 55 years $(53$ males were $<55,48$ were $\geqslant 55$ years old; 10 females were $<55$ and 12 were $\geqslant 55$ years old) and smoking periods were between 5 and 58 years with a mean of 32 years. The main criteria accepted for the control group consisted of not having any medical treatment for a local or systemic disease and not being admitted to a hospital in the last 2 months (Table 1).

Blood samples $(5 \mathrm{ml})$ were obtained from the patient group with primary lung carcinoma at the time of diagnosis and the second samples were obtained at the end of the following month. Similarly, the first blood samples were obtained from the control group at the time they were selected and the second samples were obtained at the end of the first month. Serological studies were performed with a Chlamydophila pneumoniae MIF kit (Orgenium). In these kits, the elementary bodies of

Table 1. Baseline characteristics of lung carcinoma cases matched with the controls

Values given are number of cases or controls, with percentage in parentheses.

\begin{tabular}{|c|c|c|c|c|}
\hline \multirow[t]{2}{*}{ Characteristic } & \multicolumn{2}{|c|}{ Male } & \multicolumn{2}{|c|}{ Female } \\
\hline & $\begin{array}{c}\text { Cases } \\
(n=101)\end{array}$ & $\begin{array}{l}\text { Controls } \\
(n=101)\end{array}$ & $\begin{array}{c}\text { Cases } \\
(n=22)\end{array}$ & $\begin{array}{l}\text { Controls } \\
(n=22)\end{array}$ \\
\hline \multicolumn{5}{|l|}{ Age at diagnosis (years) } \\
\hline$<50$ & $31(30)$ & $31(30)$ & $10(45)$ & $10(45)$ \\
\hline $50-59$ & $24(24)$ & $24(24)$ & $4(18)$ & $4(18)$ \\
\hline $60-69$ & $24(24)$ & $24(24)$ & $6(27)$ & $6(27)$ \\
\hline $70-79$ & $15(15)$ & $15(15)$ & $2(9)$ & $2(9)$ \\
\hline $80-89$ & $6(6)$ & $6(6)$ & - & - \\
\hline$\geqslant 90$ & $1(1)$ & $1(1)$ & - & - \\
\hline Total & 101 & 101 & 22 & 22 \\
\hline \multicolumn{5}{|l|}{ Last recorded smoking status ${ }^{\star}$} \\
\hline Former smoker & $14(14)$ & $14(14)$ & $13(59)$ & $13(59)$ \\
\hline Current smoker & $87(86)$ & $87(86)$ & $9(41)$ & $9(41)$ \\
\hline \multicolumn{5}{|l|}{ Duration of smoking (years) } \\
\hline$<10$ & $18(18)$ & $18(18)$ & $7(32)$ & $7(32)$ \\
\hline $10-19$ & $30(30)$ & $30(30)$ & $9(41)$ & $9(41)$ \\
\hline $20-29$ & $22(22)$ & $22(22)$ & $3(14)$ & $3(14)$ \\
\hline $30-39$ & $17(17)$ & $17(17)$ & $2(9)$ & $2(9)$ \\
\hline $40-49$ & $11(11)$ & $11(11)$ & $1(4)$ & $1(4)$ \\
\hline$\geqslant 50$ & $3(3)$ & $3(3)$ & - & - \\
\hline \multicolumn{5}{|l|}{ No. cigarettes $\left(\right.$ day $\left.^{-1}\right)$} \\
\hline$<5$ & $1(1)$ & $1(1)$ & $1(4)$ & $1(4)$ \\
\hline $5-9$ & $4(4)$ & $4(4)$ & $3(14)$ & $3(14)$ \\
\hline $10-19$ & $31(31)$ & $31(31)$ & $14(64)$ & $14(64)$ \\
\hline$\geqslant 20$ & $66(66)$ & $66(66)$ & $4(18)$ & $4(18)$ \\
\hline \multicolumn{5}{|l|}{ Living environment $\dagger$} \\
\hline Same province-district and street & $97(96)$ & $97(96)$ & $19(86)$ & $19(86)$ \\
\hline $\begin{array}{l}\text { Same province-district and } \\
\text { neighbouring street }\end{array}$ & $4(4)$ & $4(4)$ & $3(14)$ & $3(14)$ \\
\hline
\end{tabular}

${ }^{*}$ While matching individually a lung carcinoma case with a control case by the history of patients with lung cancer at the last recording, the parameters of being a former or a current smoker and the number of cigarettes smoked per day between the beginning and the quitting of smoking in control groups were taken into consideration.

†While matching individually a lung carcinoma case with the control case for living environment, efforts were made to find a control case living in the same province-district and street as the lung carcinoma case. If this was not possible, efforts were made to find a control case living in the same province-district but on a street neighbouring the lung carcinoma case. 
Chlamydophila pneumoniae were used as an antigen on slides. In order to eliminate contradictory results, Chlamydia trachomatis and Chlamydophila psittaci antigens were used as controls. Serum dilutions were started at $1 / 8$ for IgG and at 1/10 for IgA and continued in twofold dilutions. As a conjugate, FITC-labelled goat anti-human IgA and IgG were used and all were evaluated by the same investigator (B. K.) using a fluorescence microscope with $40 \times 0.65$ oil-immersion objective. Seropositivity criteria for the diagnosis of chronic Chlamydophila pneumoniae infection were $\operatorname{IgG} \geqslant 512$ and $\operatorname{IgA} \geqslant 40$ and for the community population titres of $\operatorname{IgG} \geqslant 16$ were accepted as the criterion for previous infection. In both the patient and the control groups, the highest result among the first or second blood samples was accepted as the final titre (Leinonen et al., 1991; Saikku, 1993; Grayston et al., 1989; Forsey et al., 1986).

The Mc-Namar test was used in univariate analysis because patient and control groups were matched individually. Logistic regression method was used for the multivariate analysis. Forward conditional method was selected for this model.

\section{RESULTS}

Basic characteristics of the matched lung cancer group and patient group are shown in Table 1 . The number of cases having infection with titres $\geqslant 16$ was $98(79.7 \%)$ for the patient group and $54(43.2 \%)$ for the control group $(P<0 \cdot 001)$, as shown in Table 2 . There was a significant difference between male patients with lung cancer and their control group for specific Chlamydophila pneumoniae antibody titres of IgG $\geqslant 16$, IgG 512 and IgA $40(P<0 \cdot 001)$. On the other hand, female patients and their control group showed no significant difference. However serological evidence of chronic Chlamydophila pneumoniae infection was found more often in male patients with lung cancer than female patients (Table 3 ). The comparison of lung carcinoma cases with the control group, on the basis of percentage prevalence of the specific antibody seropositivity of Chlamydophila pneumoniae at titres of $\operatorname{IgG} \geqslant 512$ and $\operatorname{Ig} A \geqslant 40$ based on age and sex, is shown in Table 4. Titres indicative of chronic Chlamydophila pneumoniae infection were significantly higher in male patients with lung carcinoma below age 55 than the control group $\left[\chi^{2} 28 \cdot 66, P<0 \cdot 001\right.$, odds ratio
(OR) 18, CI (95\%) 6.2-51·8]. Conversely, no difference was found between male patients with lung carcinoma over age 55 and the control group $(P>0 \cdot 05)$. No significant difference was detected in the serological results between female patients and the female control group below age 55 and over age 55 years $(P>0 \cdot 05)$. Variants included in the logistic regression model are shown in the legend to Table 5 . According to this they were found to be significant. In the multiple logistic regression model, $\operatorname{IgG} \geqslant 16$ and $\operatorname{IgA} \geqslant 40$ were found significant. Results were determined for each variant in order for IgG $\geqslant 16 \beta=1.684, P<0.0001$, OR $5 \cdot 38$, CI (95\%) 2.939-9.866 and for IgA $\geqslant 40 \beta=1.684$, $P<0.0001$, OR $4 \cdot 583$, CI (95\%) 2.525-8.32. According to this, the risk of the raised antibody titres at $\operatorname{IgG} \geqslant 16$ and $\operatorname{IgA} \geqslant 40$ is greater in the patient group than in the control group. The number of the cases having infection with titres of $\operatorname{IgG} \geqslant 512$ and $\operatorname{Ig} A \geqslant 40$ was $62(50 \cdot 4 \%)$ for the patient group; 41 lung carcinomas were of the small-cell type (Table $6)$.

\section{DISCUSSION}

Saikku et al. $(1988,1992)$ demonstrated the seroepidemiological correlation between coronary heart diseases and atherosclerosis and infection by Chlamydophila pneumoniae, and proposed that chronic chlamydia infection of the upper and lower respiratory tract may initiate acute myocardial infarction and may be the cause of chronic arthritis in atherosclerosis. Grayston et al. (1993) and Kuo et al. (1993) have shown the presence of Chlamydophila pneumoniae in atheromatous plaques. In the following years, the occurrence of Chlamydophila pneumoniae in atherosclerotic plaques in arteries other than the coronaries, such as the carotids, was demonstrated by seroepidemiological, immunohistochemical and molecular biological methods, leading to implication of this bacterium in aetiology and pathogenesis (Yamashita et al., 1998; Maass et al., 1998). Studies concerning the role of Chlamydophila pneumoniae in the pathogenesis of juvenile arthritis and reactive arthritis in distal

Table 2. Distribution of patient and control groups according to variables

\begin{tabular}{|c|c|c|c|}
\hline \multirow[t]{2}{*}{ Patients } & \multicolumn{3}{|c|}{ Controls } \\
\hline & $\operatorname{IgG} \geqslant 16$ & IgG $<16$ & Total \\
\hline $\operatorname{IgG} \geqslant 16^{*}$ & 34 & 64 & 98 \\
\hline $\operatorname{IgG}<16$ & 18 & 7 & 25 \\
\hline \multirow[t]{2}{*}{ Total } & 52 & 71 & 123 \\
\hline & $\operatorname{IgG} \geqslant 512+\operatorname{Ig} A \geqslant 40 \dagger$ & $\operatorname{IgG}<512+\operatorname{IgA}<40$ & Total \\
\hline $\operatorname{IgG} \geqslant 512+\operatorname{Ig} A \geqslant 40 \dagger$ & 16 & 46 & 62 \\
\hline $\operatorname{IgG}<512+\operatorname{Ig} A<40$ & 9 & 52 & 61 \\
\hline Total & 25 & 98 & 123 \\
\hline
\end{tabular}


Table 3. Distribution of patient and control groups according to sex

\begin{tabular}{|c|c|c|c|c|c|c|}
\hline \multirow[t]{3}{*}{ Patients } & \multicolumn{6}{|c|}{ Controls } \\
\hline & \multicolumn{3}{|c|}{ Male } & \multicolumn{3}{|c|}{ Female } \\
\hline & $\operatorname{IgG} \geqslant 16$ & IgG $<16$ & Total & $\mathrm{IgG} \geqslant 16$ & IgG $<16$ & Total \\
\hline $\operatorname{IgG} \geqslant 16$ & $34^{*}$ & 54 & 88 & $6 \ddagger$ & 4 & 10 \\
\hline Total & $\operatorname{IgG} \geqslant 512+\operatorname{IgA} \geqslant 40$ & $\operatorname{IgG}<512+\operatorname{IgA}<40$ & Total & $\operatorname{IgG} \geqslant 512+\operatorname{IgA} \geqslant 40$ & $\operatorname{IgG}<512+\operatorname{IgA}<40$ & Total \\
\hline $\operatorname{IgG} \geqslant 512+\operatorname{Ig} A \geqslant 40$ & $12 \dagger$ & 42 & 54 & $4 \S$ & 4 & 8 \\
\hline $\operatorname{IgG}<512+\operatorname{Ig} A<40$ & 8 & 39 & 47 & 2 & 12 & 14 \\
\hline Total & 20 & 81 & 101 & 6 & 16 & 22 \\
\hline
\end{tabular}

${ }^{\star} P<0.0001$.

$\dagger P<0.0001$.

$\ddagger P>0.05$.

$\$ P>0 \cdot 05$.

Table 4. Distribution of male patient and control groups according to the criterion of 55 years old

\begin{tabular}{|c|c|c|c|c|c|c|}
\hline \multirow[t]{3}{*}{ Patients } & \multicolumn{6}{|c|}{ Controls } \\
\hline & \multicolumn{3}{|c|}{$<55$ years $^{\star}$} & \multicolumn{3}{|c|}{$\geqslant 55$ years $\dagger$} \\
\hline & $\operatorname{IgG} \geqslant 512+\operatorname{IgA} \geqslant 40$ & $\operatorname{IgG}<512+\operatorname{Ig} A<40$ & Total & $\operatorname{IgG} \geqslant 512+\operatorname{IgA} \geqslant 40$ & IgG $<512+\operatorname{IgA}<40$ & Total \\
\hline $\operatorname{IgG} \geqslant 512+\operatorname{Ig} A \geqslant 40$ & 6 & 36 & 42 & 5 & 7 & 12 \\
\hline
\end{tabular}

${ }^{\star} P<0 \cdot 0001$.

$\dagger P>0.05$.

Table 5. Results of logistic regression according to the forward conditional model

Abbreviations: B, beta regression coefficient; SE, standard error; Wald, test statistics used for the determination of the meaning of variables; d.f., degrees of freedom; Sig., significant; Exp (B), exponent; $\mathrm{Cl}$, confidence interval. Variables included in logistic regression model were age, sex, IgG16, IgG512, IgA40 and IgG 512+IgA 40.

\begin{tabular}{|c|c|c|c|c|c|c|c|c|}
\hline & \multirow[t]{2}{*}{ B } & \multirow[t]{2}{*}{$\mathrm{SE}$} & \multirow[t]{2}{*}{ Wald } & \multirow[t]{2}{*}{ d.f. } & \multirow[t]{2}{*}{ Sig. } & \multirow[t]{2}{*}{$\operatorname{Exp}(B)$} & \multicolumn{2}{|c|}{$\begin{array}{c}95.0 \% \text { CI for Exp } \\
\text { (B) }\end{array}$} \\
\hline & & & & & & & Lower & Upper \\
\hline IgG16(1) & 1684 & 309 & 29697 & 1 & .000 & 5385 & 2939 & 9866 \\
\hline $\operatorname{IgG40(1)}$ & 1522 & 304 & 25042 & 1 & .000 & 4583 & 2525 & 8320 \\
\hline
\end{tabular}


Table 6. Distribution of chronic Chlamydophila pneumoniae infection with $\lg G \geqslant 512$ and $\lg A \geqslant 40$ according to histological type of lung carcinoma

\begin{tabular}{|lcc|}
\hline Lung carcinoma $(\boldsymbol{n})$ & \multicolumn{2}{c|}{ Infection } \\
\cline { 2 - 3 } & $\boldsymbol{n}$ & $\%$ \\
\hline Small cell (70) & 41 & $58 \cdot 5$ \\
Squamous cell (28) & 14 & 50 \\
Adenocarcinoma (18) & 6 & $33 \cdot 3$ \\
Large cell (7) & 1 & $14 \cdot 28$ \\
Total (123) & 62 & $50 \cdot 4$ \\
\hline
\end{tabular}

extremities (Moazed et al., 1996; Kol et al., 1998) and the study of Blasi et al. (1997) on the relationship between sarcoidosis and Chlamydophila pneumoniae showed correlations on the basis of seropositivity; however, Chlamydophila pneumoniae was not detected by nested PCR in tissue samples. Recently, Anttila et al. (1998) have detected Chlamydophila pneumoniae-specific antibodies at high titres in 72 patients with lymphoma. In all studies, the common question was whether Chlamydophila pneumoniae had an effect in initiating the disease or merely shows affinity for preformed lesions. Most investigators (Kol et al., 1998; Moazed et al., 1996, 1997) accept the idea that the infection chain in the respiratory tract is initiated by the infection of monocytes. The agent, which proliferates in the monocytes and macrophages, provokes the pathogenesis and is responsible for the clinical symptoms. Clinical symptoms start with the antigenic response, followed by the infection of new monocytes, endothelial cells, and macrophages in the intima and smooth muscle cells in the media layer, so that cytokines and acute-phase proteins become active, producing chronic inflammation. In recent years, some investigators have suggested that Chlamydophila pneumoniae has a different role in the aetiopathogenesis, for example the high Chlamydophila pneumoniae antibody titres detected in lung carcinomas found in smokers (Laurila et al., 1997a, b; Koyi et al., 1999). In this study, chronic Chlamydophila pneumoniae infection seropositivity was found in $50 \cdot 81 \%$ of the patient group, and small-cell and squamous-cell carcinomas were detected especially in the cases with chronic Chlamydophila pneumoniae infection seropositivity. Laurila et al. (1997b) found evidence that Chlamydophila pneumoniae infection was present especially in patients with small-cell and squamous-cell carcinomas selected among 230 smokers with lung carcinoma. Koyi et al. (1999) reported that in Sweden in 1993, seropositivity ratios were significantly different from the control group in 117 smokers with lung carcinoma. Korvenan et al. (1994) showed the significant correlation of seropositivity of Chlamydophila pneumoniae with smoking. von Hertzen et al. (1998) suggested that smoking destroys lung and bronchial immunity, increases the secretion of IL4, and as a result, humoral immunity increases and cellular immunity is suppressed, so Chlamydophila pneumoniae can localize easily in the lung. Some studies (Ohshima \& Bartsch,
1994; Redecke et al., 1998) explain the pathogenesis of Chlamydophila pneumoniae infections as invasion of the lung with the help of smoking: superoxide oxygen radicals, TNF- $\alpha$, IL1 $\beta$ and IL 8 , which are produced and secreted by the monocytes activated by the antigen and the macrophages in the intima, then cause damage to lung tissue and DNA that results in carcinogenesis; in particular, IL8 is known to cause genetic damage. Another suggestion is that, by unknown mechanisms, Chlamydophila pneumoniae infection causes irregular apoptosis in tissues (Fan et al., 1998).

In this study, a significant difference was found between male patients who smoked and controls in IgG positivity at titres $\geqslant 16$; male smokers had a greater level of contact with Chlamydophila pneumoniae in the past $(P<0 \cdot 001)$. In a recent study, it has been stated that in people below age 60 years, specific Chlamydophila pneumoniae IgA positivity at titres of 216 is independently related to carcinoma (Jackson et al., 2000). A group of investigators in Sweden has indicated that male patients particularly had a high level of contact with Chlamydophila pneumoniae (IgG $\geqslant 32$ positivity) in the past, and these patients had IgG $\geqslant 512$ and IgA $\geqslant 64$ values which were significantly higher than the control group: even $48 \%$ of the young male patients were shown to have IgA titres of $\geqslant 512$ (Koyi et al., 1999). It has been reported that patients with lung carcinoma have very high titres of IgA. We have found the risk of the elevation of titration of Chlamydophila pneumoniae antibody titres at $\operatorname{IgA} \geqslant 40$ is greater in the lung cancer group than the control group according to the multivariate regression analysis.

In this study, $54 \%$ of the male patients and $36 \%$ of the female patients were diagnosed as having chronic seropositivity for Chlamydophila pneumoniae, and a significant difference was found in male patients when compared $(P<0.001)$ with the control group (Table 5). This difference was especially seen in male patients below the age of 55. In a Finnish study, the seropositivity ratios of chronic Chlamydophila pneumoniae was found to be high in 231 male smoking patients below the age of 60 . Similar results have been reported with studies dealing with male patients who were smokers below the age of 70 and above the age of 60 (Laurila et al., 1997a; Koyi et al., 1999; Jackson et al., 2000).

However, age and sex are not thought to be factors in the multivariate analysis. As a result, the detection of chronic Chlamydophila pneumoniae infection in young, smoking, male lung carcinoma patients, at high ratios in univariate analysis and the elevation of $\operatorname{IgG} \geqslant 16$ and $\operatorname{IgA} \geqslant 40$ titres compared with the control group, suggests that infection together with age, sex and smoking is a high risk factor in lung carcinoma development. It is not possible to conclude from this study whether chronic Chlamydophila pneumoniae infection will increase the risk of lung cancer or whether patients with lung cancer will be at greater risk of picking up Chlamydophila pneumoniae. In order to define the possible association between chronic Chlamydophila pneumoniae infection and lung cancer, further studies with a larger number of cases are necessary. 


\section{ACKNOWLEDGEMENTS}

I would like to thank Professor Dr Seyhan Çelikoğlu from the Kadir Has University, Florence Nightingale Hospital, Thoracic Diseases Dept, and Dr A. Suat Sarıbas from the Cerrahpasa Faculty of Medicine Microbiology and Clinical Microbiology Dept, and also my co-workers, Dr Mesut Gencay and Kadir Sağlam for their contributions to this study.

\section{REFERENCES}

Anttila, T. I., Lehtinen, T., Leinonen, M., Bloigu, A., Koskela, P., Lehtinen, M. \& Saikku, P. (1998). Serological evidence of an association between chlamydial infections and malignant lymphomas. $\mathrm{Br} \mathrm{J} \mathrm{Hae-}$ matol 103, 150-156.

Arat, A., Kocazeybek, B., Enar, R., Orhon, R. \& Pehlivanoğlu, S. (1999). Chlamydia pneumoniae kararlı Anjina Pektoris iliskisi. 15. Ulusal Kardiyoloji Kongresi 9-12 Ekim 1999 İzmir 362.

Blasi, F., Rizzato, G., Gambacorta, M. \& 8 other authors (1997). Failure to detect the presence of Chlamydia pneumoniae in sarcoid pathology specimens. Eur Respir J 10, 2609-2611.

Everett, K. D. E., Bush, R. M. \& Andersen, A. A. (1999). Emended description of the order Chlamydiales, proposal of Parachlamydiaceae fam. nov. and Simkaniaceae fam. nov., each containing one monotypic genus, revised taxonomy of the family Chlamydiaceae, including a new genus and five new species, and standards for the identification of organisms. Int J Syst Evol Microbiol 49, 415-440.

Fan, T., Lu, H., Hu, H., Shi, L., McClarty, G. A., Nance, D. M., Greenberg, A. H. \& Zhong, G. (1998). Inhibition of apoptosis in chlamydia-infected cells: blockade of mitochondrial cytochrome c release and caspase activation. J Exp Med 187, 487-496.

Forsey, T., Darougar, S. \& Treharne, J. D. (1986). Prevalence in human beings of antibodies to Chlamydia IOL-207, an atypical strain of chlamydia. J Infect 12, 145-152.

Gaydos, C. A., Fowler, C. L., Gill, V. J., Eiden, J. J. \& Quinn, T. C. (1993). Detection of Chlamydia pneumoniae by polymerase chain reactionenzyme immunoassay in an immunocompromised population. Clin Infect Dis 17, 718-723.

Grayston, J. T. (1989). Chlamydia pneumoniae strain TWAR. Chest 95, 664-669.

Grayston, J. T. (1994). Chlamydia pneumoniae (TWAR) infections in children. Pediatr Infect Dis J 13, 675-684.

Grayston, J. T., Wang, S. P., Kuo, C. C. \& Campbell, L. A. (1989). Current knowledge on Chlamydia pneumoniae, strain TWAR, an important cause of pneumonia and other acute respiratory diseases. Eur J Clin Microbiol Infect Dis 8, 191-202.

Grayston, J. T., Campbell, L. A., Kuo, C. C., Mordhorst, C. H., Saikku, P., Thom, D. H. \& Wang, S. P. (1990). A new respiratory tract pathogen: Chlamydia pneumoniae strain TWAR. J Infect Dis 161, 618-625.

Grayston, J. T., Kuo, C. C., Campbell, L. A. \& Benditt, E. P. (1993). Chlamydia pneumoniae, strain TWAR and atherosclerosis. Eur Heart $J$ 14 (Suppl.), 66-71.

Jackson, L. A., Wang, S. P., Nazar-Stewart, V., Grayston, J. T. \& Vaughan, T. L. (2000). Association of Chlamydia pneumoniae immunoglobulin A seropositivity and risk of lung cancer. Cancer Epidemiol Biomark Prev 9, 1263-1266.

Karvonen, M., Tuomilehto, J., Pitkaniemi, J., Naukkarinen, A. \& Saikku, P. (1994). Importance of smoking for Chlamydia pneumoniae seropositivity. Int J Epidemiol 23, 1315-1321.

Kol, A., Sukhova, G. K., Lichtman, A. H. \& Libby, P. (1998). Chlamydial heat shock protein 60 localizes in human atheroma and regulates macrophage tumor necrosis factor-alpha and matrix metalloproteinase expression. Circulation 98, 300-307.

Koyi, H., Branden, E., Gnarpa, J., Gnarpe, H., Arnholm, B. \& Hillerdal, G. (1999). Chlamydia pneumoniae may be associated with lung cancer. Preliminary report on a seroepidemiological study. APMIS 107, $828-832$

Kuo, C. C., Shor, A., Campbell, L. A., Fukushi, H., Patton, D. L. \& Grayston, J. T. (1993). Demonstration of Chlamydia pneumoniae in atherosclerotic lesions of coronary arteries. J Infect Dis 167, 841-849.

Laurila, A. L., Anttila, T., Laara, E., Bloigu, A., Virtamo, J., Albanes, D., Leinonen, M. \& Saikku, P. (1997a). Serological evidence of an association between Chlamydia pneumoniae infection and lung cancer. Int $J$ Cancer 74, 31-34.

Laurila, A. L., Von Hertzen, L. \& Saikku, P. (1997b). Chlamydia pneumoniae and chronic lung diseases. Scand J Infect Dis Suppl 104, $34-36$

Leinonen, M., Syrjala, H., Kujala, P. \& Saikku, P. (1991). Serological diagnosis of C. pneumoniae in adults. In Abstracts of 31st ICAAC, Chicago, Illinois, 29 September-2 October 1991, p. 209. Washington, DC: American Society for Microbiology.

Maass, M., Bartels, C., Engel, P. M., Mamat, U. \& Sievers, H. H. (1998), Endovascular presence of viable Chlamydia pneumoniae is a common phenomenon in coronary artery disease. J Am Coll Cardiol 31, 827-832.

Moazed, T. C., Kuo, C., Patton, D. L., Grayston, J. T. \& Campbell, L. A. (1996). Experimental rabbit models of Chlamydia pneumoniae infection. Am J Pathol 148, 667-676.

Moazed, T. C., Kuo, C., Grayston, J. T. \& Campbell, L. A. (1997). Murine models of Chlamydia pneumoniae infection and atherosclerosis. J Infect Dis 175, 883-890.

Ohshima, H. \& Bartsch, H. (1994). Chronic infections and inflammatory processes as cancer risk factors: possible role of nitric oxide in carcinogenesis. Mutat Res 305, 253-264.

Redecke, V., Dalhoff, K., Bohnet, S., Braun, J. \& Maass, M. (1998). Interaction of Chlamydia pneumoniae and human alveolar macrophages: infection and inflammatory response. Am J Respir Cell Mol Biol 5, 721-727.

Saikku, P. (1992). The epidemiology and significance of Chlamydia pneumoniae. J Infect 25 (Suppl.), 27-34.

Saikku, P. (1993). Chlamydia pneumoniae infection as a risk factor in acute myocardial infarction. Eur Heart J 14 (Suppl.), 62-65.

Saikku, P., Leinonen, M., Mattila, K., Ekman, M. R., Nieminen, M. S. Makela, P. H., Huttunen, J. K. \& Vaitonen, V. (1988). Serological evidence of an association of a novel Chlamydia, TWAR, with chronic coronary heart disease and acute myocardial infarction. Lancet ii, 983-986.

Saikku, P., Leinonen, M., Tenkanen, L., Linnanmaki, E., Ekman, M. R., Manninen, V., Manttari, M., Frick, M. H. \& Huttunen, J. K. (1992). Chronic Chlamydia pneumoniae infection as a risk factor for coronary heart disease in the Helsinki Heart Study. Ann Intern Med 116, 273-278.

Thom, D. H. \& Grayston, J. T. (1991). Infections with Chlamydia pneumoniae strain TWAR. Clin Chest Med 12, 245-256.

von Hertzen, L., Surcel, H. M., Kaprio, J., Koskenvuo, M., Bloigu, A., Leinanen, M. \& Saikku, P. (1998). Immune responses to of $C$. pneumoniae in twins in relation to gender and smoking. J Med Microbiol $47,441-446$

Yamashita, K., Ouchi, K., Shirai, M., Gondo, T., Nakazawa, T. \& Ito, H. (1998). Distribution of Chlamydia pneumoniae infection in the atherosclerotic carotid artery. Stroke 29, 773-778. 